\title{
SEPARATION AND CONCENTRATION OF MOLYBDENUM(VI) AND TUNGSTEN(VI) WITH CHELATING ION-EXCHANGE RESINS CONTAINING SULPHUR LIGANDS
}

\author{
Chuen-Ying Liu* and Peng-Joung Sun \\ Department of Chemistry, National Taiwan University, Taipei, Taiwan
}

(Received 29 April 1983. Revised 24 November 1983. Accepted 7 December 1983)

\begin{abstract}
Summary-Three chelating ion-exchange resins based on macroreticular polyacrylonitrile-divinylbenzene copolymers with thioglycollic acid and cysteine as functional groups have been tested for separation of molybdenum(VI) and tungsten(VI). On a short column of the thioglycollic acid resin, molybdenum(VI) and tungsten(VI) can be selectively sorbed from $\mathrm{pH}-4.3$ acetate buffer and eluted with $2 M$ hydrochloric acid and a mixture of $0.1 M$ sodium hydroxide and $0.1 M$ sodium chloride, respectively, with quantitative recovery even at very low concentrations. Simulated sea-water samples have been analysed.
\end{abstract}

The synthesis and characterization of chelating ionexchange resins containing thioglycollic acid and cysteine as functional groups, and their analytical applications to noble metals, have been described. ${ }^{1,2}$ As part of a systematic survey of the behaviour of metal ions with these resins, the chromatography of molybdenum(VI) and tungsten(VI) species has now been studied.

\section{EXPERIMENTAL}

\section{Instrumentation}

A Radiometer $\mathrm{pH}$-meter was used with saturated calomel (Type K 401) and glass (Type G 202 B) electrodes, and calibrated with Beckman standard buffers of $\mathrm{pH} 4.00$ and 7.00. A Hitachi model 624 digital spectrophotometer connected to a Hitachi model $\mathrm{QD}_{15}$ recorder was used, with 10-mm quartz cells.

\section{Reagents}

Previously published procedures were used to synthesize the macroreticular polyacrylonitrile-divinylbenzene copolymers. ${ }^{1.2}$ The nitrile groups were hydrolysed to carboxylic acid groups. The carboxylic acid resin $(200 \mathrm{~g})$ was mixed with $600 \mathrm{~g}$ of molten 1,6-hexanediol (m.p. $41^{\circ}$ ) or $500 \mathrm{~g}$ of ethylene glycol, and $40 \mathrm{ml}$ of concentrated sulphuric acid (as catalyst), and kept at $70^{\circ}$ for $30 \mathrm{hr}$ for the first esterification. Then a mixture of $150 \mathrm{~g}$ of this product with $460 \mathrm{~g}$ of thioglycollic acid and $40 \mathrm{ml}$ of concentrated sulphuric acid was reacted at $70^{\circ}$ for $30 \mathrm{hr}$ for the second esterification. The 1,6-hexanediol or ethylene glycol served both as linking agent and reaction medium, the products being Resins I and II respectively.' The carboxylic acid resin was similarly treated with 1,6-hexanediol and L-cysteine in a two-step esterification to give Resin III. ${ }^{2}$ The final product was collected by filtration under suction and washed sequentially with water, concentrated hydrochloric acid, water and acetonc.

\footnotetext{
*Author for correspondence.
}

Spectrophotometric determination of molybdenum $(V I)$ and tungsten (VI)

The procedures used were essentially those reported by Sandell. ${ }^{3}$ Maximum colour development and stability were obtained with ascorbic acid as reducing agent for the determination of molybdenum(VI). The sensitivity was increased by extraction of the molybdenum( $V$ ) and tungsten(V) thiocyanate complexes into n-butyl acetate.

\section{Sorption by the batch method}

Exactly $0.3 \mathrm{~g}$ of dry polymer was pre-equilibrated with 20 $\mathrm{ml}$ of $1 M$ sodium perchlorate- $0.5 M$ sodium acetate mixture, the $\mathrm{pH}$ being periodically adjusted to the required value with perchloric acid or sodium hydroxide until it had remained constant for $6 \mathrm{hr}$. The solution was removed by filtration. The metal ion solution $(10 \mathrm{ml}, 0.062 M)$ was then added to $10 \mathrm{ml}$ of $2 M$ sodium perchlorate and $10 \mathrm{ml}$ of $1 M$ sodium acetate, and the $\mathrm{pH}$ adjusted to the required value. The prepared metal ion solution, diluted to $50 \mathrm{ml}$, was added to the pre-equilibrated polymer and stirred for $18 \mathrm{hr}$. The $\mathrm{pH}$ was then checked for constancy, and the resin was filtered off and washed with the appropriate acetate buffer. The filtrate and washings were combined and analysed for molybdenum(VI) or tungsten(VI).

The distribution coefficient for molybdenum(VI), as a function of hydrochloric acid concentration, was also delermined by a batch equilibrium method; $25 \mathrm{ml}$ of a mixture containing various amounts of acid and 0.4 mmole of metal ion were stirred with $0.2 \mathrm{~g}$ of air-dried resin for $18 \mathrm{hr}$ at $25^{\circ}$. The resin was filtered off and washed, and the molybdenum(VI) in the filtrate was determined.

\section{Equilibration rates}

From the capacity studies, the total capacity of each resin for molybdenum(VI) and tungsten(VI) at the optimal $\mathrm{pH}$ was known. Twice the quantity of molybdenum(VI) or tungsten(VI) corresponding to saturation of $0.3 \mathrm{~g}$ of resin at $\mathrm{pH} 4.3$ was diluted in the appropriate buffer to give $0.03 \mathrm{M}$ metal ion concentration. Then $0.3 \mathrm{~g}$ of the air-dried resin was introduced into this solution and equilibrated. Samples of solution were removed at intervals and their metal ion content was determined. 
Separation of molybdenum(VI) and tungsten $(V I)$

Resin I was packed into a glass tube $(10 \times 0.6 \mathrm{~cm})$ and conditioned with $20 \mathrm{ml}$ of $1 M$ acetate buffer (pH 4.3). After conditioning, $9.3 \mu$ moles each of molybdenum(VI) and tungsten(VI) were loaded on to the column, and molybdenum(VI) was eluted with $2 M$ hydrochloric acid at 0.5 $\mathrm{ml} / \mathrm{min}$. Tungsten(VI) was retained on the column and then eluted with $0.1 M$ sodium hydroxide- $0.1 M$ sodium chloride mixture at the same flow-rate.

\section{Concentration of trace metals}

Portions $(500 \mathrm{ml})$ of water containing various amounts of molybdenum(VI) or tungsten(VI) were adjusted to pI 4.3 and passed at $0.5 \mathrm{ml} / \mathrm{min}$ through a preconditioned $7.0 \times 0.6$ $\mathrm{cm}$ resin column, and the molybdenum(VI) and tungsten(VI) eluted as above and determined. Recovery of 9.70 $\mu \mathrm{g}$ of molybdenum(VI) and $0.01 \mu \mathrm{g}$ of tungsten(VI) from 1 litre of simulated sea-water ${ }^{4}$ was similarly determined.

\section{RESULTS AND DISCUSSION}

The pH-dependence of the sorption behaviour of Resins I-III towards molybdenum(VI) and tungsten(VI) was tested by the batch equilibrium method. Table 1 shows the distribution coefficients obtained. Resins I and II, which contained the same functional groups but different linking agents, behaved similarly. The length of the linking agent slightly influenced the capacity. The similarity of the distribution coefficients for molybdenum(VI) and tungsten(VI) at $\mathrm{pH} \mathrm{2-7}$ prevents simple separation of the metals in this $\mathrm{pH}$ range. The distribution coefficients for molybdenum(VI) between hydrochloric acid and Resins I-III are shown in Table 2. Tungsten(VI) precipitated from the acid solution, so could not be studied. Molybdenum(VI) or tungsten(VI) at $\mathrm{pH} 4.3$ was used to assess the kinetics of sorption, $50 \%$ of the

Table 1. Distribution coefficients for molybdenum(VI) and tungsten(VI) on the three resins

\begin{tabular}{|c|c|c|c|c|c|}
\hline \multirow[b]{2}{*}{$\mathrm{pH}$} & \multicolumn{2}{|c|}{ Resin I } & \multirow{2}{*}{$\frac{\text { Resin II }}{\text { Mo }}$} & \multicolumn{2}{|c|}{ Resin III } \\
\hline & Mo & W & & Mo & W \\
\hline 1.60 & & & & 166 & \\
\hline 2.20 & & & 11 & & \\
\hline 2.25 & 11 & & & & \\
\hline 2.28 & & & & & 47 \\
\hline 3.40 & 65 & & 49 & 18 & 47 \\
\hline 3.70 & & 25 & & & \\
\hline 3.80 & 71 & & 94 & 17 & \\
\hline 4.10 & 73 & & 100 & 18 & \\
\hline 4.28 & & 35 & & & \\
\hline 4.30 & 71 & & 97 & 26 & 55 \\
\hline 4.40 & & & 90 & & \\
\hline 4.80 & 60 & 35 & 60 & 11 & \\
\hline 4.86 & & & & & 51 \\
\hline 4.95 & & 36 & & & \\
\hline 5.15 & 53 & & 40 & 4 & \\
\hline 5.25 & & & 26 & & \\
\hline 5.95 & 11 & & & & \\
\hline 6.05 & & & & & 26 \\
\hline $\begin{array}{l}6.12 \\
6.58\end{array}$ & 26 & 37 & & & \\
\hline $\begin{array}{l}6.58 \\
7.10\end{array}$ & & & 26 & & \\
\hline $\begin{array}{l}7.10 \\
7.30\end{array}$ & & & & 11 & \\
\hline
\end{tabular}

Table 2. Distribution coefficients of molybdenum(VI) on the three resins in hydrochloric acid

\begin{tabular}{lrrrrrrrr}
\hline & \multicolumn{8}{c}{ Concentration of $\mathrm{HCl}, \mathbf{M}$} \\
\cline { 2 - 8 } Resin & 0.1 & 0.5 & 1 & 2 & 4 & 5 & 6 & 7 \\
\hline I & 75 & 25 & 16 & 1 & 27 & 43 & 38 & 30 \\
II & 56 & 19 & 12 & 2 & 31 & 49 & 36 & 29 \\
III & 64 & 82 & 72 & 62 & 42 & 42 & 41 & 40 \\
\hline
\end{tabular}

available sites of Resin I being occupied by molybdenum(VI) and tungsten(VI) in $12 \mathrm{~min}$ and $21 \mathrm{~min}$, respectively. From the results of the batch equilibrium study, the possibility of separating molybdenum(VI) and tungsten(VI) by using a Resin I column was obvious. The molybdenum(VI) and tungsten(VI) sorbed can be easily stripped quantitatively from the resin column in succession by $2 M$ hydrochloric acid and $0.1 \mathrm{M}$ sodium hydroxide $0.1 \mathrm{M}$ sodium chloride mixture, respectively. Figure 1 shows such a separation.

The effect of foreign ions on the recovery of molybdenum(VI) and tungsten(VI) with Resin I was studied. The results are reported in Table 3. Since the sulphur content of Resin I was $1.56 \mathrm{mmole} / \mathrm{g}$, the silver(I) capacity was $1.52 \mathrm{mmole} / \mathrm{g}$, the mercury(II) capacity was $0.80 \mathrm{mmole} / \mathrm{g}$, the molybdenum(VI) capacity was $0.75 \mathrm{mmole} / \mathrm{g}$, and the tungsten(VI) capacity was $0.35 \mathrm{mmole} / \mathrm{g}$, silver(I) and mercury(II) interfered severely, even if the mole ratio to molybdenum or tungsten was reduced to 1 , whereas copper(II), zinc(II) and tin(IV) did not interfere at this concentration ratio. The resin exhibited no affinity for the alkali and alkaline-earth metals studied. Small quantities of the resin can therefore be used to concentrate trace metals from samples with a high electrolyte content, such as sea-water and biological

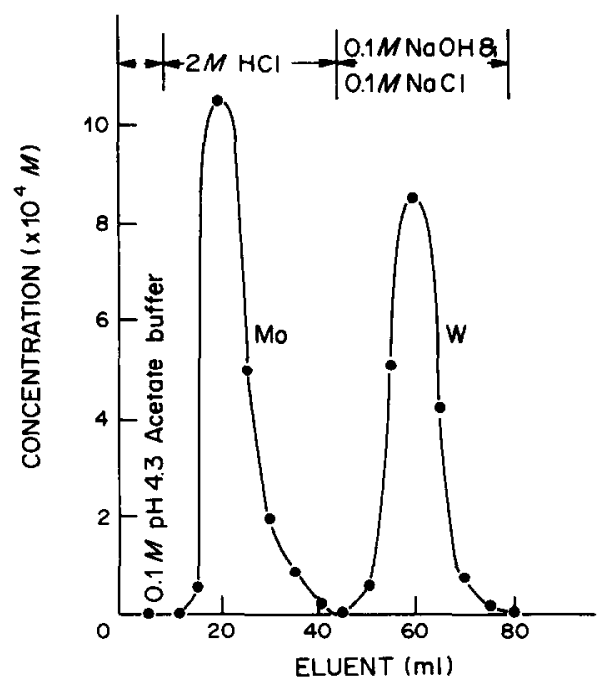

Fig. 1. Separation of molybdenum(VI) and tungsten(VI) with Resin I: (Column $10.0 \times 0.6 \mathrm{~cm}$ bore, flow-rate 0.5 $\mathrm{ml} / \mathrm{min} ; 9.3 \mu$ mole of each metal absorbed). 
Table 3. Effects of foreign ions on the recovery of molybdenum(VI) and tungsten(VI) (35 $\mu \mathrm{g}$ each) respectively, with Resin I

\begin{tabular}{lccc}
\hline $\begin{array}{c}\text { Foreign } \\
\text { metal }\end{array}$ & $\begin{array}{c}\text { Amount } \\
\text { added, } m g\end{array}$ & $\begin{array}{c}\text { Molybdenum } \\
\text { found, } \mu g\end{array}$ & $\begin{array}{c}\text { Tungsten } \\
\text { found, } \mu g\end{array}$ \\
\hline $\mathrm{Ag}^{+}$ & 0.04 & 6.0 & 5.1 \\
$\mathrm{~K}^{+}$ & 5 & 35.0 & 35.0 \\
$\mathrm{Na}^{+}$ & 5 & 35.0 & 35.0 \\
$\mathrm{Ca}^{2+}$ & 2 & 35.0 & 35.0 \\
$\mathrm{Co}^{2+}$ & 1 & 35.0 & 37.3 \\
$\mathrm{Cu}^{2+}$ & 0.02 & 33.6 & 33.0 \\
$\mathrm{Hg}^{2+}$ & 0.07 & 17.4 & 15.1 \\
$\mathrm{Mg}^{2+}$ & 1 & 35.0 & 35.1 \\
$\mathrm{Mn}^{2+}$ & 1 & 35.0 & 34.9 \\
$\mathrm{Ni}^{2+}$ & 1 & 35.0 & 38.1 \\
$\mathrm{~Pb}^{2+}$ & 0.07 & 33.1 & 30.1 \\
$\mathrm{Zn}^{2+}$ & 0.02 & 24.9 & 35.0 \\
$\mathrm{Al}^{3+}$ & 1 & 34.9 & 34.9 \\
$\mathrm{Fe}^{3+}$ & 10 & 35.0 & 36.1 \\
$\mathrm{Sn}^{4+}$ & 0.04 & 34.9 & 33.0 \\
$\mathrm{U}(\mathrm{VI})$ & 1 & 34.8 & 35.0 \\
$\mathrm{~W}(\mathrm{VI}) \dagger$ & 1 & 35.0 & \\
\hline
\end{tabular}

* In the presence of 5 drops of $10 \%$ ascorbic acid solution. $\dagger$ In the presence of 5 drops of $10 \%$ sodium tartrate solution.
Table 5. Preconcentration and determination of molybdenum(VI) and tungsten(VI) in simulated sea-water*

\begin{tabular}{cccc}
$\begin{array}{c}\text { Metal } \\
\text { ion }\end{array}$ & $\begin{array}{c}\text { Amount } \\
\text { added, } \\
\mu g\end{array}$ & $\begin{array}{c}\text { Amount } \\
\text { found, } \\
\mu g\end{array}$ & $\begin{array}{c}\text { Recovery of } \\
\text { total metal, } \\
\%\end{array}$ \\
\hline Mo(VI) $\dagger$ & 0.0 & 9.4 & 97 \\
& 10.2 & 19.9 & 100 \\
W(VI)§ & 10.3 & 11.1 & 98 \\
& 10.3 & 11.1 & 98 \\
\hline
\end{tabular}

* Metal content in original sample: $\mathrm{Mo}=9.70 \mu \mathrm{g} / \mathrm{l}$, $\mathrm{W}=0.10 \mu \mathrm{g} / \mathrm{l}$.

† Sample 1 litre.

§ Sample 10 litres.

fluids, since the resin would not become salurated by the alkali or alkaline-earth metals present.

Very low concentrations of molybdenum(VI) and tungsten(VI) in pure water and simulated sea-water can be concentrated with Resin I before their determination. Tables 4 and 5 show the recoveries.

Table 4. Recovery of metal ions from very dilute solution with Resin I

\begin{tabular}{lclcc}
\hline $\begin{array}{c}\text { Metal } \\
\text { ion }\end{array}$ & $\begin{array}{c}\text { Amount added } \\
\mu \text { mole }\end{array}$ & \multicolumn{1}{c}{ Eluent } & $\begin{array}{c}\text { Amount found, } \\
\mu \text { mole }\end{array}$ & $\begin{array}{c}\text { Recovery, } \\
\%\end{array}$ \\
\hline Mo(VI) & 0.37 & $2 M \mathrm{HCl}$ & 0.37 & 100 \\
$\mathrm{Mo}(\mathrm{VI})$ & 0.104 & $2 M \mathrm{HCl}$ & 0.100 & 96 \\
W(VI) & 0.37 & $0.1 M \mathrm{NaOH}-0.1 M \mathrm{NaCl}$ & 0.37 & 100 \\
W(VI) & 0.37 & $0.5 M \mathrm{NaOH}-0.5 M \mathrm{NaCl}$ & 0.37 & 100 \\
W(VI) & 0.025 & $0.1 M \mathrm{NaOH}-0.1 M \mathrm{NaCl}$ & 0.021 & 84 \\
\hline
\end{tabular}

* In $500 \mathrm{ml}$ of $\mathrm{pH}-4.30 .1 \mathrm{M}$ acetate buffer.

Table 6. Colour imparted to the solution by the three resins with excess of molybdenum ions

\begin{tabular}{|c|c|c|c|}
\hline \multirow{2}{*}{$\begin{array}{l}\text { pH or } \\
\text { acidity }\end{array}$} & \multicolumn{3}{|c|}{ Colour } \\
\hline & Resin I & Resin II & Resin III \\
\hline $7 M \mathrm{HCl}$ & green & green & pale yellow \\
\hline $6 M \mathrm{HCl}$ & green & green & pale yellow \\
\hline $5 M \mathrm{HCl}$ & brown & brown & pale yellow \\
\hline $3 M \mathrm{HCl}$ & brown & brown & pale yellow \\
\hline $2 M \mathrm{HCl}$ & yellow-brown & yellow-brown & pale yellow \\
\hline $1 M \mathrm{HCl}$ & yellow-brown & yellow-brown & pale yellow \\
\hline $0.5 M \mathrm{HCl}$ & yellow-brown & yellow-brown & pale yellow \\
\hline $0.1 M \mathrm{HCl}$ & blue & blue & blue \\
\hline $\mathrm{pH} 1.60$ & - & - & blue \\
\hline $\mathrm{pH} 2.20$ & - & blue & - \\
\hline $\mathrm{pH} 2.25$ & blue & - & - \\
\hline $\mathrm{pH} 3.80$ & - & - & colourless \\
\hline pH 4.00 & green & - & - \\
\hline $\mathrm{pH} 4.10$ & - & green & - \\
\hline $\mathrm{pH} 4.30$ & 一 & - & colourless \\
\hline $\mathrm{pH} 4.40$ & - & green & - \\
\hline $\mathrm{pH} 4.80$ & yellow-green & - & - \\
\hline $\mathrm{pH} 5.15$ & - & - & colourless \\
\hline pH 5.25 & - & pale green & - \\
\hline $\mathrm{pH} 5.95$ & yellow-green & - & - \\
\hline $\mathrm{pH} 6.12$ & colourless & - & - \\
\hline $\mathrm{pH} 7.10$ & - & colourless & - \\
\hline $\mathrm{pH} 7.30$ & - & - & colourless \\
\hline
\end{tabular}


Molybdenum(VI) can be reduced to molybdenum(V) in $2 M$ hydrochloric acid and to molybdenum(III) at higher acid concentrations. ${ }^{5}$ The colours imparted to the solution by the chelating ion-exchange resins in presence of molybdenum(VI) species are listed in Table 6. The colours, taken in conjunction with those of chemical forms of molybdenum(V) at various concentrations of hydrochloric acid, ${ }^{5}$ suggest that molybdenum(VI) is reduced by the resins, e.g. to molybdenum(V) in $0.5 M$ hydrochloric acid. Because of this reductive behaviour of the resin, the possibility of using the Mo-thioglycollic acid and Mo-cysteine resin systems for catalysing hydrogenation reactions is obvious. Investigation of the catalytic behaviour of these systems in the nitrogenase reaction as model are in progress.

Acknowledgement-This work was supported by a grant from the National Science Council of the Republic of China, to which many thanks are due.

\section{REFERENCES}

1. C. Y. Liu and P. J. Sun, J. Chinese Chem. Soc., 1981, 28, 75.

2. Idem, Anal. Chim. Acta, 1981, 132, 187.

3. E. B. Sandell, Colorimetric Determination of Traces of Metals, 3rd Ed., Interscience, New York, 1959.

4. L. G. Danielsson, B. Magnusson and S. Westerlund, Anal. Chim. Acta, 1978, 98, 47.

5. G. Charlot, Qualitative Inorganic Analysis, Methuen, London, 1963. 